\title{
Total Phenolic and Flavonoid Content and Biological Activities of Extracts and Isolated Compounds of Cytisus villosus Pourr.
}

\author{
Farida Larit ${ }^{1,2, *}$, Francisco León ${ }^{1,3} \oplus^{(}$, Samira Benyahia ${ }^{4}$ and Stephen J. Cutler ${ }^{1,5}$ \\ 1 Department of BioMolecular Sciences, School of Pharmacy, University of Mississippi, \\ University, MS 38677-1848, USA; JLeonOyola@cop.ufl.edu (F.L.); SJCUTLER@cop.sc.edu (S.J.C.) \\ 2 Département de Chimie, Faculté des Sciences Exactes, Université des Frères Mentouri Constantine 1, \\ Constantine, Route d'Aine El Bey, 25000 Constantine, Algeria \\ 3 Department of Medicinal Chemistry, College of Pharmacy, University of Florida, Gainesville, FL 32610, USA \\ 4 Laboratoire de Synthèse Organique, Modélisation et Optimisation des Procèdes (LOMOP), Université Badji \\ Mokhtar, Faculté des Sciences, Département de Chimie, 23000 Annaba, Algeria; \\ samira.benyahia13@gmail.com \\ 5 College of Pharmacy, University of South Carolina, Columbia, SC 29208, USA \\ * Correspondence: laritfarida@umc.edu.dz; Tel.: +213-664-79-89
}

Received: 19 October 2019; Accepted: 11 November 2019; Published: 13 November 2019

\begin{abstract}
The aim of this study was to evaluate the total phenolic and flavonoid content, and the in vitro antioxidant, anti-inflammatory, antibacterial, antifungal, antimalarial, cytotoxicity, and antiprotozoal activities of the Algerian plant Cytisus villosus Pourr. (Syn. Cytisus triflorus L'Hérit.). Additionally, the radioligand displacement affinity on opioid and cannabinoid receptors was assessed for the extracts and isolated pure compounds. The hydro alcoholic extract of the aerial part of $C$. villosus was partitioned with chloroform $\left(\mathrm{CHCl}_{3}\right)$, ethyl acetate (EtOAc), and $n$-butanol $(n-\mathrm{BuOH})$. The phenolic content of the $C$. villosus extracts was evaluated using a modified Folin-Ciocalteau method. The total flavonoid content was measured spectrometrically using the aluminum chloride colorimetric assay. The known flavonoids genistein (1), chrysin (2), chrysin-7-O- $\beta$-D-glucopyranoside (3), and 2"-O- $\alpha$-L-rhamnosylorientin (4) were isolated. The antioxidant activities of the extracts and isolated compounds were evaluated using 2,2-diphenyl-1-picrylhydrazyl (DDPH) and cellular antioxidant activity (CAA) assays. The plant extracts showed moderate antioxidant activity. EtOAc and $n-\mathrm{BuOH}$ extracts showed moderate anti-inflammatory activity through the inhibition of induced nitric oxide synthase (iNOS) with $\mathrm{IC}_{50}$ values of 48 and $90 \mu \mathrm{g} / \mathrm{mL}$, respectively. The isolated pure compounds 1 and 3 showed good inhibition of Inducible nitric oxide synthase (iNOS) with $\mathrm{IC}_{50}$ values of 9 and $20 \mu \mathrm{g} / \mathrm{mL}$, respectively. Compounds 1 and 2 exhibited lower inhibition of Nuclear Factor kappa-light-chain-enhancer of activated B cells (NF- $\mathrm{kB}$ ) with $\mathrm{IC}_{50}$ values of 28 and $38 \mu \mathrm{g} / \mathrm{mL}$, respectively. Furthermore, the extracts and isolated pure compounds have been shown to exhibit low affinity for cannabinoid and opioid receptors. Finally, $n-\mathrm{BuOH}$ extract was a potent inhibitor of Trypanosoma brucei with $\mathrm{IC}_{50}$ value of $7.99 \mu \mathrm{g} / \mathrm{mL}$ and $\mathrm{IC}_{90}$ value of $12.61 \mu \mathrm{g} / \mathrm{mL}$. The extracts and isolated compounds showed no antimicrobial, antimalarial nor antileishmanial activities. No cytotoxic effect was observed on cancer cell lines. The results highlight this species as a promising source of anti-inflammatory and antitrypanosomal agents.
\end{abstract}

Keywords: Cytisus villosus; antioxidant; anti-inflammatory; antibacterial; antifungal; antimalarial; antileishmanial; antitrypanosomal; cytotoxicity; cannabinoid receptor; opioid receptor 


\section{Introduction}

Natural compounds derived from plants have played an important role from ancient to recent times in the management and treatment of many maladies with wide effects, such as antioxidants associated with reduced risks of cancer, cardiovascular disease, diabetes, infectious diseases, and other disorders associated with age [1]. The advantage of many natural products, which have been components of the human diet for several thousand years, is that the human organism has become adapted to them, which may decrease the risk of harmful side effects.

Polyphenols are a major class of natural compounds of medicinal importance, exhibiting a wide range of biological and pharmacological activities, such as antioxidant, anti-inflammatory, immunostimulant, anti-aging, antitumor, antidepressant, and antiparasitic [2,3]. The high antioxidant activity of polyphenols is mainly due to their redox properties, which allow them to act as reducing agents, hydrogen donors, and singlet oxygen quenchers. In this context, oxidative stress plays an important role in the progression of neurodegenerative conditions, including rheumatic and cardiovascular disorders, metabolic syndrome, and other diseases [4]. Inflammation is considered to be a risk factor for hypertension, diabetes, and several types of cancer, and can be involved in Alzheimer's disease pathogenesis.

Nuclear factor-kappa B (NF-kB), inducible nitric oxide synthase (iNOS), and reactive oxygen species (ROS) have long been considered as important targets for new anti-inflammatory drugs. NF- $\kappa B$ plays a central role in inflammation through its ability to induce transcription of proinflammatory genes, hence, NF- $\mathrm{B}$ h has been implicated in the pathogenesis of many inflammatory and age-associated diseases [5]. NF-КB complex proteins are widely expressed in the developing and mature nervous system. The effects of NF-kB on neurons have been widely investigated and, recently, it has been reported that the NF- $\mathrm{KB}$ family of transcription factors has a major role in regulating the growth and elaboration of neural processes [6]. Furthermore, NF-kB has been found to play a role in enhancing neuronal apoptosis associated with ischemic brain injury, neurodegenerative diseases, and inflammatory conditions [7,8]. In fact, Bonini et al. [9] demonstrated that there are potential links between the altered function of the NF- $\kappa$ B pathway and pathogenesis of neurodevelopmental disorders [9]. Excessive generation of nitric oxide (NO) and ROS contribute significantly to the progress of inflammation [10]. Inhibition of iNOS can reduce the intracellular NO production [11].

Infections caused by several protozoa microorganism, including Trypanosoma, Plasmodium, and Leishmania, are a major worldwide health problem causing significant morbidity and mortality in Africa, Asia, and South America. According to the World Health Organization (WHO) statistics, there are 12 million people currently affected by leishmaniasis in 88 countries, including Algeria with 350 million people at risk [12]. Current available drugs for the treatment of these infections suffer from high toxicities, which may cause serious side effects. Thus, there is an urgent need to develop safer and more efficient compounds for the treatment of these diseases. Polyphenols, specifically flavonoids, have been known to be important resources to find new antiprotozoal, non-toxic drug candidates $[13,14]$.

Several herbs used in folk medicine have been suggested as important sources for treatment of depression, Alzheimer's and Parkinson's diseases, and other neuropsychiatric as well as neurological disorders [15-17]. The interaction of medicinal plants with central nervous system (CNS) receptors is well reported [18-20]. Specifically, the opioid system has been described to play different roles in inflammation, the cancer process, and to be a potential target for therapy of various neurological disorders [21-23]. The case of cannabinoid receptors (CB1 and CB2) has gained much attention as potential pharmacotherapeutic targets to control some CNS disorders, in particular those related to neuroinflammatory and neurodegenerative events, such as Alzheimer's disease (AD) [24,25]. Within the last decade, medicine based on opioids and cannabinoids has found many applications, including as anti-inflammatory agents and analgesics [26,27].

Cytisus (Fabaceae) is a large and diversified genus, including approximately 60 species, which are particularly abundant around the Mediterranean Sea [28]. Plants of this genus have been used in 
folk medicine as a diuretic and in the treatment of mild hypertension, heart failure, cardiac edema, and wounds. Cytisus species have been found to exhibit bioactive properties, including antioxidant, anti-inflammatory, anxiolytic, antiparasitic, and antidiabetic activities [29-31]. The therapeutic properties of Cytisus are related to their high concentration of phenolic compounds, including flavonoids and caffeic acids [32]. In continuation of previous works on Algerian plants [33,34], herein, we extended our study to evaluate the antioxidant, anti-inflammatory, antiprotozoal, antimalarial, antimicrobial, cytotoxicity, and radioligand displacement affinity on opioid and cannabinoid receptors activities of extracts and isolated pure compounds of Cytisus villosus Pourr. (Syn. Cytisus triflorus L'Hérit.).

\section{Materials and Methods}

\subsection{General Experimental Procedures}

UV spectra were obtained using a Perkin-Elmer Lambda 3B UV/vis-spectrophotometer (Perkin Elmer Inc, Waltham MA, USA). ${ }^{1} \mathrm{H}$ and ${ }^{13} \mathrm{C}$ NMR spectra were obtained using Bruker model AMX 500 and 400 NMR spectrometers with standard pulse sequences, operating at 500 and $400 \mathrm{MHz}$ in ${ }^{1} \mathrm{H}$ and 125 and $100 \mathrm{MHz}$ in ${ }^{13} \mathrm{C}$, respectively. Coupling constants were recorded in Hertz (Hz). Standard pulse sequences were used for Heteronuclear and homonuclear 2D NMR experiments. All spectra were run at $25^{\circ} \mathrm{C}$. High-resolution mass spectra (HRMS) (Bruker Corporation, Billerica MA, USA) were measured on a Micromass Q-Tof Micro mass spectrometer with a lock spray source (Waters Corporation, Milford MA, USA). Column chromatography was carried out on silica gel (70-230 mesh, Merck, Darmstadt, Germany), C18 Solid Phase extraction (SPE) (500 mg Bed, Thermo scientific INC, Waltham MA, USA), Diaion HP-20 (Sorbetch technologies, Norcross GA, USA), and sephadex LH-20 (Sorbetch technologies Norcross GA, USA USA). Thin Layer Chromatography (TLC) (silica gel 60 F254, Merck, Darmstadt, Germany) was used to monitor fractions from column chromatography. Preparative TLC was carried out on silica gel 60 PF254+366 plates $(20 \times 20 \mathrm{~cm}, 1 \mathrm{~mm}$ thick). Visualization of the TLC plates was achieved with a UV lamp $(\lambda=254$ and $365 \mathrm{~nm})$ and anisaldehyde/acid spray reagent (MeOH-acetic acid-anisaldehyde-sulfuric acid, 85:9:1:5).

\subsection{Plant Material}

The aerial parts of Cytisus villosus Pourr. were collected from the Collo region, in Northeastern Algeria during its flowering stage in April 2010. A voucher specimen (UM-10232015) has been deposited in the culture collection of the Department of BioMolecular Sciences, University of Mississippi.

\subsection{Extraction and Isolation}

Dried powdered aerial parts of $C$. villosus $(1 \mathrm{~kg})$ were macerated at room temperature with $\mathrm{EtOH}-\mathrm{H}_{2} \mathrm{O}(80: 20, v / v)$ for $24 \mathrm{~h}$, three times. The filtered crude extracts were combined and concentrated under reduced pressure to afford $25 \mathrm{~g}$ of extract, which was suspended in distilled water $(800 \mathrm{~mL})$ and successively partitioned with chloroform $\left(\mathrm{CHCl}_{3}\right)$, ethyl acetate (EtOAc), and n-butanol (n-but), yielding $500 \mathrm{mg}\left(\mathrm{CHCl}_{3}\right), 5 \mathrm{~g}$ (EtOAc), and $10 \mathrm{~g}$ ( $n$-butanol) fractions, respectively. The ethyl acetate fraction ( $5 \mathrm{~g}$ ) was subjected to silica gel column, eluted initially with $\mathrm{CH}_{2} \mathrm{Cl}_{2}$ : $\mathrm{MeOH}(95: 5)$ and then gradient eluted with $\mathrm{CH}_{2} \mathrm{Cl}_{2}$ : $\mathrm{MeOH}$ at ratios 90:10, 85:15, 80:20, 50:50, 20:80, and finally with 100\% $\mathrm{MeOH}$. Each subfraction was monitored by TLC on silica gel using $\mathrm{CHCl}_{3}$ :EtOAc:HCOOH (5:4:1) and $\mathrm{CH}_{2} \mathrm{Cl}_{2}: \mathrm{MeOH}(1: 1)$ systems. Similar subfractions were combined together and concentrated under reduced pressure to yield seven main subfractions (I to VII). Subfraction II (170 mg) was subjected to Sephadex LH-20 column using $\mathrm{MeOH}$ as the solvent to afford compound 1 ( $5 \mathrm{mg}$, genistein) as light-yellow needles. Subfraction III (161 mg) was subjected to Sephadex LH-20 using MeOH as an eluent to yield compound $2(4 \mathrm{mg})$ as a yellow amorphous powder. Subfraction V (250 mg) was subjected to Sephadex $\mathrm{LH}-20$ using $\mathrm{MeOH}: \mathrm{CH}_{2} \mathrm{Cl}_{2}(1: 1)$ as an eluent to give compound 3 (3 mg) as a yellowish amorphous powder. The $n$-BuOH fraction (10 g) was subjected to Diaion HP-20 column 
chromatography and eluted with distilled $\mathrm{H}_{2} \mathrm{O}$ then $\mathrm{MeOH}$ to give two main subfractions, the aqueous subfraction A (6 g) and the methanolic subfraction M (4 g). The methanolic subfraction M (4 g) was subjected to MN-polyamide-SC-6 (150 g) column chromatography which was eluted with water and then with water-methanol systems gradient decreased polarities to afford eight subfractions (M-1 to M-8). Subfraction M-3 (250 mg) was rechromatographed on Sephadex LH-20 column eluted with $\mathrm{MeOH}: \mathrm{CH}_{2} \mathrm{Cl}_{2}(1: 1)$ to yield compound $4(6 \mathrm{mg})$ as yellow crystals.

\subsection{Determination of Total Phenolic and Total Flavonoid Content}

Folin-Ciocalteu reagent, gallic acid, and quercetin standards were obtained from Sigma-Aldrich (Poznan, Poland). Aluminum chloride hexahydrate, methanol, and sodium carbonate were obtained from Sigma-Aldrich (Poznan, Poland). The total phenolic was measured using spectrophotometry with a modified Folin-Ciocalteu method [35]. Total phenol content, expressed as milligrams of gallic acid equivalent (GAE) per gram of extract (GAE $\mathrm{mg} / \mathrm{g}$ ), was calculated on the basis of a standard calibration curve of gallic acid $\left(Y=0.1157 x+0.087, R^{2}=0.9749\right)$. Total flavonoid content of the plants fractions crud extracts was determined by colorimetric method [36,37]. The concentration of total flavonoid content in the test samples was calculated from the calibration plot $(Y=1.2308 x+0.0151$, $\left.R^{2}=0.9775\right)$ and expressed as $\mathrm{mg}$ quercetin equivalent $(\mathrm{QE}) / \mathrm{g}$ of dried extract. The extracts were dissolved in dimethyl sulfoxide (DMSO) to make a stock solution of $20 \mathrm{mg} / \mathrm{mL}$.

\subsection{Antioxidant Activity}

\subsubsection{Diphenyl-1-picrylhydrazyl (DPPH) Assay}

The antioxidant activity of the extracts and pure isolated compounds was determined by applying the 2,2-diphenyl-1-picrylhydrazyl (DPPH) radical scavenging method [38].

\subsubsection{Cellular Antioxidant Activity (CAA) Assay}

The cellular antioxidant activity was measured in HepG2 cells as described by Wolfe and Rui $[39,40]$. The antioxidant activity was expressed in terms of CAA units. The area under the curve (AUC) of fluorescence versus time plot was used to calculate CAA units as described by Wolfe and Rui [39,40].

\subsection{Anti-Inflammatory Activity}

\subsubsection{Anti-Inflammatory Activity Assay for the Inhibition of iNOS}

The extracts and isolated compounds of $C$. villosus were evaluated in terms of their interaction with cellular targets related to inflammation and metabolic disorders, such as iNOS and NF- $\mathrm{kB}$. The inhibition of intracellular NO production as a result of iNOS activity was assayed in mouse macrophages (RAW 264.7cells) [41]. Cytotoxicity of test samples to macrophages was also determined in parallel to check if the inhibition of iNOS was due to cytotoxic effects.

\subsubsection{Reporter Gene Assay for the Inhibition of NF-kB}

Reporter gene assay for the inhibition of NF- $\kappa B$ Activity was performed as described earlier [42]. In brief, cells transfected with NF- $\mathrm{kB}$ luciferase plasmid construct were plated in 96-well plates at a density of $1.25 \times 105$ cells/well. After $24 \mathrm{~h}$, cells were treated with the test compounds and, after incubating for $30 \mathrm{~min}$, phorbol 12-myristate 13-acetate (PMA) (Sigma-Aldrich, Burlington MA, USA) $(70 \mathrm{ng} / \mathrm{mL})$ was added and further incubated for $6-8 \mathrm{~h}$. Luciferase activity was measured as described above. Percent decrease in luciferase activity was calculated relative to the vehicle control. Parthenolide (Sigma-Aldrich, Burlington MA, USA) was used as a positive control. 


\subsection{Antiprotozoal Assay}

The in vitro antileishmanial and antitrypanosomal assays were done on cell cultures of $L$. donovani promastigotes, axenic amastigotes, THP1-amastigotes, and Trypanosoma brucei trypomastigotes by Alamar Blue assays [43]. The conditions for seeding the THP1 cells, exposure to the test samples, and evaluation of cytotoxicity were the same as described in parasite-rescue and transformation assay [44]. $\mathrm{IC}_{50}$ and $\mathrm{IC}_{90}$ values were computed from the dose response curves using XLfit software (XLfit 5.3.1, IDBS analytical, Boston MA, USA). DFMO (difluoromethylornithine) was used as the positive control. The antiprotozoal activity of $C$. villosus extracts and isolated compounds were evaluated in vitro against $L$. donovani promastigotes, axenic amastigotes, and intracellular amastigotes in THP1 cells. The extracts and some isolated compounds were also evaluated against T. brucei trypomastigote forms. All the extracts and compounds were simultaneously tested against THP1 cell for determination of general cytotoxicity. The extracts and isolated compounds were also evaluated for their antimalarial activity against chloroquine-sensitive (D6, Sierra Leone) and chloroquine-resistant strains (W2, Indochina) strains of Plasmodium falciparum [45]. Furthermore, they were tested for cytotoxicity against the Vero cell line.

\subsection{Antimicrobial Assay}

Extracts and pure compounds were tested for their antimicrobial activity against Staphylococcus aureus, methicillin-resistant S. aureus (MRSA), Escherichia coli, Pseudomonas aeruginosa, and Mycobacterium intracellulare. The antifungal activities were evaluated against a panel of pathogenic fungi, including Candida albicans, C. glabrata, C. krusei, Aspergillus fumigatus, and Cryptococcus neoformans, associated with opportunistic infections. Ciprofloxacin (MP Biomedicals Inc, Aurora OH, USA) for antibacterial bioassays and Amphotericin B (MP Biomedicals Inc, Aurora OH, USA) for fungal bioassays were used as positive controls, respectively [45].

\subsection{Cytotoxicity Assays}

Each assay was performed in 96-well tissue culture-treated microplates. Cytotoxic activity was determined against four human cancer cell lines (SK-MEL, KB, BT-549, andSKOV-3,) and two noncancerous kidney cell lines (LLC-PK1 and Vero). All cell lines were obtained from the American Type Culture Collection (ATCC, Rockville, MD, USA). Each assay was performed in 96-well tissue culture-treated microplates [46]. Cells were seeded at a density of 25,000 cells/well and incubated for $24 \mathrm{~h}$. Samples at different concentrations were added and cells were again incubated for $48 \mathrm{~h}$. At the end of incubation, the cell viability was determined using neutral red dye according to a modification of the procedure of Borenfreund et al. [46,47]. IC $_{50}$ values were determined from dose-response curves of percent growth inhibition against test concentrations. Doxorubicin was used as a positive control, while DMSO was used as the negative (vehicle) control.

\subsection{Radioligand Displacement for Cannabinoid and Opioid Receptor Subtypes}

The evaluated extracts and isolated compounds of $C$. villosus were run in competition binding with cannabinoid receptor subtypes, cannabinoid receptor $1\left(\mathrm{CB}_{1}\right)$ and cannabinoid receptor $2\left(\mathrm{CB}_{2}\right)$, and were tested against the opioid receptor subtypes $(\mu, \kappa$, and $\delta$ ) as previously described [48].

\subsection{Statistical Analysis}

All the experiments for determination of total phenolics, total flavonoids, and antioxidant properties using DPPH and cellular antioxidant assay (CAA) were conducted in triplicates. The values are expressed as the mean \pm standard deviation (SD). Analysis of variance and significance of difference among means were tested by one-way ANOVA and least significant difference (LSD) on mean values. Correlation coefficients $(R)$ and coefficients of determination $\left(R^{2}\right)$ were calculated using Microsoft Excel 2007. 


\section{Results}

\subsection{Chemistry}

Phytochemical study of the hydro ethanolic extract of the aerial part of $C$. villosus led to the isolation of four known flavonoids (1) genistein, (2) chrysin, (3) chrysin-7-O- $\beta$-D-glucopyranoside, and (4) 2 " $-O-\alpha$-L-rhamnosylorientin (Figure 1). The structures of the known compounds were identified by comparison of their spectroscopic data with those reported in the literature [33]. The spectroscopic data for the isolated compounds can be seen the Supplementary Materials Figures S1-S12.<smiles>O=c1c(-c2ccc(O)cc2)coc2cc(O)cc(O)c12</smiles>

Genistein (1)<smiles>O=c1cc(-c2ccccc2)oc2cc(OC3OCC4(O)C(O)CC3C(O)C4O)cc(O)c12</smiles>

Chrysin -7-O- $\beta$-D-glucopyranoside (3)<smiles>O=c1cc(-c2ccccc2)oc2cc(O)cc(O)c12</smiles>

Chrysin (2)<smiles></smiles>

2"-O- $\alpha$-L-rhamnosylorientin (4)

Figure 1. Compounds isolated of Cytisus villosus aerial parts.

\subsection{Determination of Total Phenolic and Total Flavonoid Contents}

Table 1 shows the total phenolic content in the extracts of the $C$. villosus aerial parts. Total phenolic content was measured for the $\mathrm{CHCl}_{3}, \mathrm{EtOAc}$, and $n-\mathrm{BuOH}$ extracts. Among the extracts of $\mathrm{C}$. villosus, the highest phenolic content was found in the $n$-BuOH extract (363.00mg GAE/g dried extract) followed by EtOAc (208.00 mg GAE/g dried extract) and $\mathrm{CHCl}_{3}$ extract (56.00 mg GAE/g dried extract). The total flavonoids content in the C. villosus extracts are shown in Table 1. Similarly, the highest amount of flavonoid content was found in the $n$-BuOH extract $(21.16 \mathrm{mg} \mathrm{QE} / \mathrm{g}$ dried extract).

Table 1. Total phenolic, flavonoid, and radical scavenging (DPPH) activity of C. villosus extracts.

\begin{tabular}{cccccc}
\hline Extract & $\begin{array}{c}\text { Total Phenolic } \\
\text { Content (mg } \\
\text { GAE/g extract) }\end{array}$ & $\begin{array}{c}\text { Total } \\
\text { Flavonoid } \\
\text { Content }(\mathbf{m g} \\
\text { QE/g extract) }\end{array}$ & $\begin{array}{c}\text { DPPH } \\
\text { Scavenging } \\
\mathbf{I C}_{\mathbf{5 0}} \mathbf{( m g / m L}\end{array}$ & ARP = 1/IC $\mathbf{5 0}$ & $\begin{array}{c}\text { mg AAE/g } \\
\text { Extract=ARP } \\
\text { Extract/ARP } \\
\text { Ascorbic Acid }\end{array}$ \\
\hline $\mathrm{CHCl}_{3}$ & $56.0 \pm 2.50$ & $7.70 \pm 0.547$ & $0.459 \pm 0.002$ & $2.180 \pm 0.01$ & $0.093 \pm 0.004$ \\
$\mathrm{EtOAC}$ & $208.0 \pm 8.49$ & $13.95 \pm 1.058$ & $0.425 \pm 0.003$ & $2.355 \pm 0.018$ & $0.100 \pm 0.001$ \\
$n-\mathrm{BuOH}$ & $363.0 \pm 8.32$ & $21.16 \pm 1.022$ & $0.164 \pm 0.004$ & $6.113 \pm 0.157$ & $0.268 \pm 0.007$ \\
Ascorbic acid & & & $0.043 \pm 0.006$ & $23.761 \pm 3.257$ & \\
\hline
\end{tabular}

Values expressed are means \pm SD of three parallel measurements. GAE. Gallic acid equivalents; QE. Quercetin equivalents; ARP. Antiradical power. 


\subsection{Determination of Antioxidant Activity}

\subsubsection{2,2-Diphenyl-1-picrylhydrazyl (DPPH) Assay}

The antioxidant activity of extracts and isolated compounds of $C$. villosus was evaluated in terms of their free radical scavenging capacity (DPPH) assay (Figure 2). The $\mathrm{CHCl}_{3}$ and EtOAc extracts of $C$. villosus showed moderate antioxidant activity with $\mathrm{IC}_{50}$ values of 0.459 and $0.425 \mathrm{mg} / \mathrm{mL}$, respectively. The $n$-BuOH extract showed highly antioxidant activity against DDPH compared to EtOAc and $\mathrm{CHCl}_{3}$ extracts with an $\mathrm{IC}_{50}$ value of $0.164 \mathrm{mg} / \mathrm{mL}$ (Table 1 ).

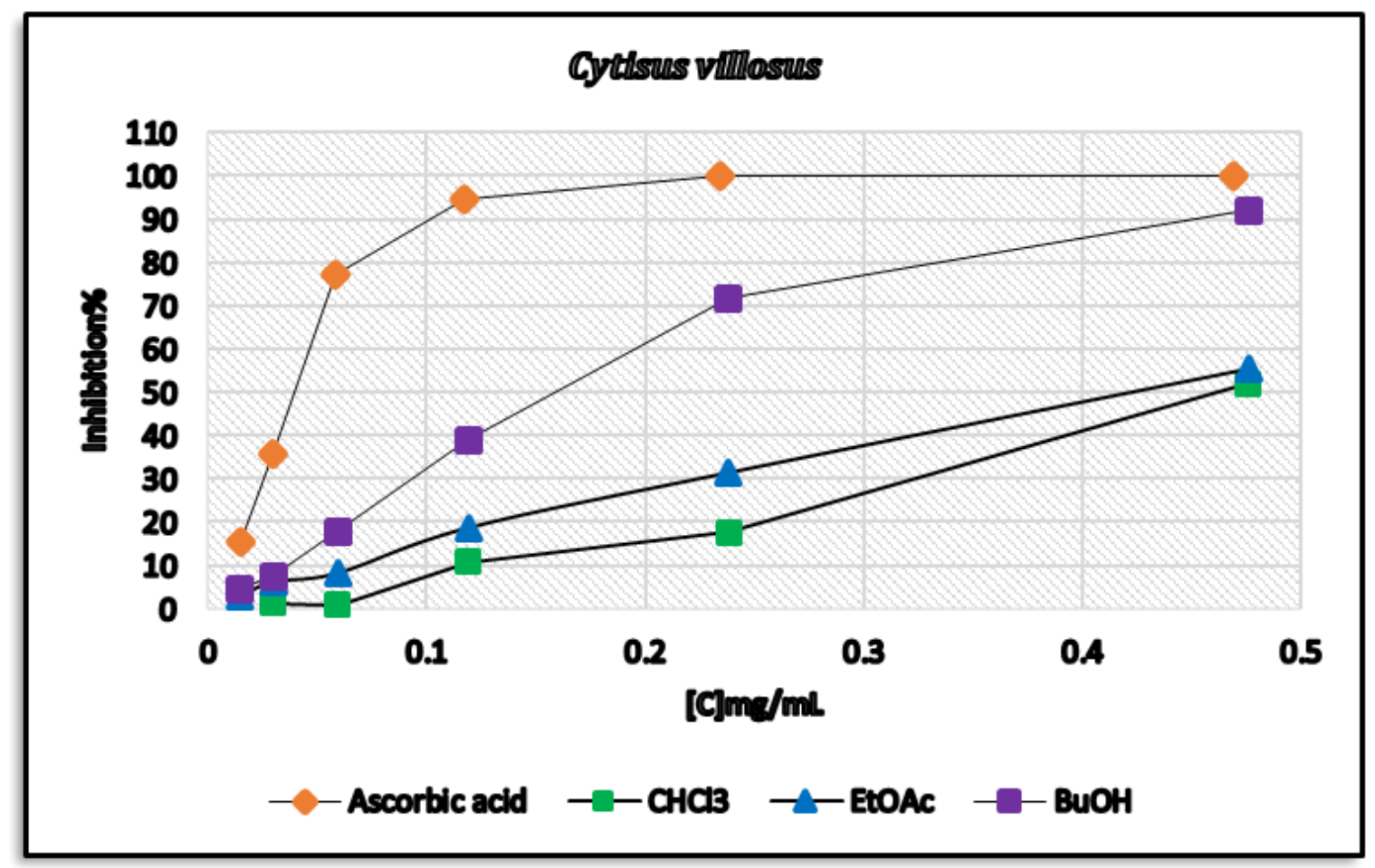

Figure 2. Radical scavenging effect of C. villosus extracts on 2,2-Diphenyl-1-picrylhydrazyl (DPPH) radical. Each value is represented as mean $\pm \mathrm{SD}$.

\subsubsection{Cellular Antioxidant Activity (CAA) assay}

The antioxidant activity of $C$. villosus extracts and isolated pure compounds was also evaluated using the cellular antioxidant assay (CAA). The results are shown in Table 2. The extracts of C. villosus showed weak inhibition of intracellular oxidative stress (29\% to 36\% inhibition of ROS generation at $250 \mu \mathrm{g} / \mathrm{mL}$ ). Similarly, the tested isolated compounds were not effective except for compound 4 from $n$-BuOH extract (Figure 2). Compound 4 showed weak inhibition of intracellular oxidative stress $(28 \%$ at $250 \mu \mathrm{g} / \mathrm{mL}$ ) (Table 2).

\subsection{Determination of Anti-Inflammatory Activity}

The EtOAc and $n$-BuOH extracts of $C$. villosus showed weak inhibition of iNOS with $\mathrm{IC}_{50}$ values of 48 and $90 \mu \mathrm{g} / \mathrm{mL}$, respectively. Compounds 1 and 3 isolated from the EtOAc extract of C. villosus showed good inhibition of iNOS with $\mathrm{IC}_{50}$ values of 9 and $20 \mu \mathrm{g} / \mathrm{mL}$, respectively (Table 3). The increase in transcriptional activity of NF-kB in PMA-treated cells was also not suppressed by the plant's extracts and isolated compounds with the exception of compounds 1 and 2, which showed moderate inhibition of NF- $\kappa$ B activity with $\mathrm{IC}_{50}$ values of 28 and $38 \mu \mathrm{g} / \mathrm{mL}$, respectively (Table 3). 
Table 2. Potential antioxidant activities of extracts and some isolated pure compounds.

\begin{tabular}{cccc}
\hline & \multicolumn{3}{c}{ \% Decrease in Oxidative Stress } \\
\hline \multirow{2}{*}{ Tested Organism } & \multicolumn{3}{c}{ Concentration $(\mu \mathrm{g} / \mathrm{mL})$} \\
& 1000 & 500 & 250 \\
\hline xtracts & & & \\
EtOAc & 47 & 37 & 29 \\
$n$-BuOH & 49 & 39 & 36 \\
Compounds & & & \\
1 & NA & NA & NA \\
2 & NA & NA & NA \\
3 & NA & NA & NA \\
4 & 36 & 29 & 28 \\
Quercetin $25 \mu \mathrm{M}$ & 77 & & \\
\hline
\end{tabular}

Table 3. Anti-inflammatory activities of extracts and some isolated compounds of C. villosus.

\begin{tabular}{|c|c|c|c|}
\hline Tested Organism & $\begin{array}{c}\text { Inhibition of iNOS } \\
\mathrm{IC}_{50}(\mu \mathrm{g} / \mathrm{mL})\end{array}$ & $\begin{array}{l}\text { Inhibition of NF-kB } \\
\operatorname{IC}_{50}(\mu \mathrm{g} / \mathrm{mL})\end{array}$ & $\begin{array}{l}\mathrm{IC}_{50} \\
\mathrm{SP}-1\end{array}$ \\
\hline \multicolumn{4}{|c|}{ Extracts } \\
\hline EtOAc & 48 & NT & NT \\
\hline $\begin{array}{c}n-\mathrm{BuOH} \\
\text { compounds }\end{array}$ & 90 & NT & NT \\
\hline 1 & 9 & 28 & NA \\
\hline 2 & $>25$ & 38 & NA \\
\hline 3 & 20 & NA & NA \\
\hline 4 & NA & NA & NA \\
\hline Parthenolide & 0.2 & 1.63 & \\
\hline
\end{tabular}

$\overline{\mathrm{NA}}=$ no activity at $25 \mathrm{or} 100 \mu \mathrm{g} / \mathrm{mL}$ for pure compounds and extracts, respectively. NT = not tested.

\subsection{Antiprotozoal Activity}

The results for this assay are presented in Table 4. The EtOAc extract showed weak antitrypanosomal activity against $T$. brucei with $\mathrm{IC}_{50}$ values of $19.48 \mu \mathrm{g} / \mathrm{mL}$, while the $n$ - $\mathrm{BuOH}$ extract was found to exhibit high antitrypanosomal activity against $T$. brucei with $\mathrm{IC}_{50}$ values of $7.99 \mu \mathrm{g} / \mathrm{mL}$ and $\mathrm{IC}_{90}$ values of $12.61 \mu \mathrm{g} / \mathrm{mL}$. No significant activity was observed in vitro against Leishmania donovani (promastigotes, axenic amastigotes, and intracellular amastigotes in THP1 cells).

\subsection{Antimicrobial Activity}

The plant's extracts and isolated compounds showed no antimicrobial activity against all tested microorganisms. The results of antimicrobial assay are given in Table 5.

\subsection{Anti-Malarial Activity}

The results of the antimalarial activity assay are presented in Tables 6 and 7. No antimalarial activity was observed against chloroquine-sensitive and chloroquine-resistant strains of Plasmodium. 
Table 4. Antiprotozoal activity of extracts and some isolated compounds of C. villosus.

\begin{tabular}{|c|c|c|c|c|c|c|c|c|c|c|}
\hline Tested Organism & $\begin{array}{l}\text { L. donovani } \\
\text { Promastigote } \\
\text { IC }_{50}(\mu \mathrm{M})\end{array}$ & $\begin{array}{l}\text { L. donovani } \\
\text { Promastigote } \\
\text { IC }_{90}(\mu \mathrm{M})\end{array}$ & $\begin{array}{c}\text { L. donovani } \\
\text { Amastigote } \\
\mathrm{IC}_{50}(\mu \mathrm{M})\end{array}$ & $\begin{array}{c}\text { L. donovani } \\
\text { Amastigote } \\
\text { IC }_{90}(\mu \mathrm{M})\end{array}$ & $\begin{array}{c}\text { L. donovani } \\
\text { Amastigote/THP1 } \\
\text { IC }_{50}(\mu \mathrm{M})\end{array}$ & $\begin{array}{c}\text { L. donovani } \\
\text { Amastigote/THP1 } \\
\text { IC } 90(\mu \mathrm{M})\end{array}$ & $\begin{array}{c}\text { T. brucei } \\
\mathrm{IC}_{50}(\mu \mathrm{M})\end{array}$ & $\begin{array}{c}\text { T. brucei } \\
\mathrm{IC}_{90}(\mu \mathrm{M})\end{array}$ & $\begin{array}{c}\text { THP1 } \\
\begin{array}{c}\text { Cytotoxicity IC } \\
(\mu \mathrm{M})\end{array}\end{array}$ & $\begin{array}{c}\text { THP1 } \\
\begin{array}{c}\text { Cytotoxicity } \mathrm{C}_{90} \\
(\mu \mathrm{M})\end{array}\end{array}$ \\
\hline \multicolumn{11}{|l|}{ Extracts } \\
\hline $\mathrm{EtOH}$ & $>20$ & $>20$ & $>20$ & $>20$ & $>20$ & $>20$ & 19.48 & $>20$ & $>20$ & $>20$ \\
\hline $\mathrm{BuOH}$ & $>20$ & $>20$ & $>20$ & $>20$ & $>20$ & $>20$ & 7.99 & 12.61 & $>20$ & $>20$ \\
\hline \multicolumn{11}{|l|}{ Compounds } \\
\hline 3 & $>10$ & $>10$ & $>10$ & $>10$ & $>10$ & $>10$ & $>10$ & $>10$ & $>10$ & $>10$ \\
\hline 4 & $>10$ & $>10$ & $>10$ & $>10$ & $>10$ & $>10$ & $>10$ & $>10$ & $>10$ & $>10$ \\
\hline Amphotericin B & 0.136 & 0.215 & 0.211 & 0.374 & 0.188 & 0.421 & NT & NT & $>2$ & $>2$ \\
\hline Pentamidine & 1.478 & 2.382 & 9.581 & $>10$ & 1.157 & 5.587 & 0.001 & 0.002 & $>10$ & $>10$ \\
\hline DFMO & NT & NT & NT & NT & NT & NT & 3.634 & 8.804 & NT & NT \\
\hline
\end{tabular}

Table 5. Antimicrobial activity of extracts and certain isolated compounds of C. villosus

\begin{tabular}{|c|c|c|c|c|c|c|c|c|c|}
\hline \multirow[b]{3}{*}{$\begin{array}{c}\text { Extract/ } \\
\text { Compound }\end{array}$} & \multicolumn{9}{|c|}{$\%$ Growth Inhibition ${ }^{1,2} / \mathrm{IC}_{50} \mathrm{\mu g} / \mathrm{mL}$} \\
\hline & \multicolumn{4}{|c|}{ Anti-Fungal } & \multicolumn{5}{|c|}{ Anti-Bacterial } \\
\hline & C. albicans & C. glabrata & C. krusei & A. fumigatus & C. neoformans & S. aureus & MRSA & E. coli & P. aeruginosa \\
\hline$n-\mathrm{BuOH}$ & 9 & 40 & 0 & 2 & 0 & 0 & 0 & 14 & 9 \\
\hline EtOAc & 9 & 11 & 2 & 4 & 0 & 3 & 0 & 12 & 5 \\
\hline 2 & $>20$ & NT & NT & NT & $>20$ & $>20$ & NT & $>20$ & $>20$ \\
\hline 3 & $>20$ & NT & NT & NT & $>20$ & $>20$ & NT & $>20$ & $>20$ \\
\hline 4 & $>20$ & NT & NT & $>20$ & $>20$ & $>20$ & $>20$ & $>20$ & $>20$ \\
\hline AMB & 100 & NT & NT & 93 & 100 & NT & 1 & 0 & 0 \\
\hline CIPRO & 0 & NT & NT & 8 & 0 & NT & 0 & 100 & 96 \\
\hline
\end{tabular}

Concentration: $50 \mu \mathrm{g} / \mathrm{mL} .{ }^{1}$ Samples showing \% Growth Inhibition $<50$ are considered inactive; ${ }^{2}$ Samples showing \% Growth Inhibition $>50$ in any organisms are confirmed in secondary assay. Ciprofloxacin $(\mathrm{CIPRO})$ and Amphotericin $(\mathrm{AMB})=$ positive controls. Pure compounds that have an $\mathrm{IC}_{50} \mathrm{of} \leq 7 \mu \mathrm{g} / \mathrm{mL}$ in the secondary assay proceeded to the tertiary assay. 
Table 6. Antimalarial activity of C. villosus extracts.

\begin{tabular}{cccc}
\hline Tested Organism & \multicolumn{3}{c}{ \%Inhibition } \\
\hline Extract & P. falciparum (D6 Clone) & P. falciparum $($ W2 Clone) & Concentration ng/mL \\
\hline BuOH & 0 & NT & 158667 \\
EtOAc & 0 & NT & 158667 \\
CQ & 100 & NT & 79.3 \\
\hline
\end{tabular}

CQ: Chloroquine (Positive Control).

Table 7. Antimalarial activity $\left(\mathrm{IC}_{50}\right.$ values are in $\left.\mathrm{ng} / \mathrm{mL}\right)$ of compound.

\begin{tabular}{ccccccc}
\hline & IC $_{\mathbf{5 0}}$ & SI & IC $_{\mathbf{5 0}}$ & SI & IC $_{\mathbf{5 0}}$ & \\
\hline $\mathrm{CQ}$ & $<26.0$ & $>9$ & 116 & $>2.1$ & $>238$ & $238-26.4$ \\
2 & $>4760$ & 1 & $>4760$ & 1 & $>4760$ & $4760-528.9$ \\
3 & $>4760$ & 1 & $>4760$ & 1 & $>4760$ & $4760-528.9$
\end{tabular}

CQ: Chloroquine (Positive Control); SI: selectivity index $\left(\mathrm{IC}_{50}\right.$ for cytotoxicity/ $/ \mathrm{IC}_{50}$ for antimalarial activity).

\subsection{Cytotoxicity}

The results of Cytotoxicity assays are shown in Table 8 . The tested extracts and isolated compounds of $C$. villosus were not active against any cell lines used in this study.

Table 8. Cytotoxic activity of $C$. villosus extracts and isolated pure compounds

\begin{tabular}{ccccccc}
\hline \multicolumn{7}{c}{ Cytotoxicity $\left(\mathrm{IC}_{\mathbf{5 0}} \boldsymbol{\mu \mathrm { g } / \mathrm { mL } )}\right.$} \\
\hline Extract/Compound & SK-MEL & KB & BT-549 & SK-OV-3 & LLC-PK1 & Vero \\
\hline EtOAc & NA & NA & NA & NA & NC & NC \\
BuOH & NA & NA & NA & NA & NC & NC \\
3 & NA & NA & NA & NA & NC & NC \\
doxorubicin & 0.8 & 1.3 & 0.9 & 2 & 1.2 & NC
\end{tabular}

$\mathrm{IC}_{50}$ is the concentration that affords $50 \%$ inhibition of cell growth. SK-MEL: Human malignant melanoma; KB: Human epidermoid carcinoma; BT-549: Human ductal carcinoma; SK-OV-3: Human ovary carcinoma; LLC-PK-1: Pig kidney epithelial cells; Vero: African green monkey kidney cell line. NA $=$ No activity at $100 \mu \mathrm{M}$. $\mathrm{NC}=$ Not cytotoxic.

\subsection{Radioligand Displacement for Cannabinoid and Opioid Receptor Subtypes}

The affinity of the total extracts and isolated compounds towards cannabinoid and opioid receptors was tested. The results are shown in Table 9. Low affinity for cannabinoids was found in both extracts evaluated and no affinity for the compound 2. For opioids, both fractions tested revealed a preference toward $\delta$-opioids with low displacement values.

Table 9. Displacement radioligand assay for human opioid receptors (Subtypes $\delta, \kappa$, and $\mu$ ) and cannabinoid receptors (Subtypes $\mathrm{CB}_{1}$ and $\mathrm{CB}_{2}$ ) of $C$. villosus.

\begin{tabular}{cccccc}
\hline & \multicolumn{3}{c}{ Cannabinoid Receptors (\%) } & \multicolumn{3}{c}{ Opioid Receptors (\%) } \\
\hline Extract/Compound & $\mathrm{CB}_{1}$ & $\mathrm{CB}_{2}$ & $\delta$ & $\kappa$ & $\mu$ \\
\hline EtOAc & 32.1 & 25.2 & 31.3 & 5.7 & 2.8 \\
$n$-BuOH & 33.7 & 26.1 & 24.8 & 10.3 & 5.7 \\
2 & 7.7 & 0.8 & 8.7 & 12.8 & 12.2 \\
naloxone & & & 106.4 & 101.6 & 97.0 \\
$\mathrm{CP} 55,940$ & 104.3 & 102.6 & & & \\
\hline
\end{tabular}

Naloxone and CP 55,940 = Positive controls. 


\section{Discussion}

The antioxidant capacity of medicinal plants extracts and pure natural compounds can be tested using various methods. In the present study, the antioxidant activity of the studied species extracts and its isolated phenolics were evaluated in terms of their free radical scavenging capacity by DPPH assay. Their activity against intracellular oxidative stress was determined by CAA assay. Our results showed that the radical scavenging activity of the $n-\mathrm{BuOH}$ extract of $C$. villosus aerial parts was high compared to the EtOAc and $\mathrm{CHCl}_{3}$ extracts. The $n$ - $\mathrm{BuOH}$ extract was found to have the highest inhibition of intracellular oxidative stress with $36 \%$ inhibition at $250 \mu \mathrm{g} / \mathrm{mL}$.

The relationship between total phenolic content and total flavonoid and antioxidant activity using DPPH assay of different extracts is shown in Figures 3 and 4, respectively. Regression analysis showed that phenolic compounds contributed to about $74 \%\left(R^{2}=0.744, p<0.05\right)$ of radical scavenging properties in the extracts of $C$. villosus (Figure 4). Similarly, flavonoid compounds contributed to about $74 \%\left(R^{2}=0.736, p<0.05\right)$ of antioxidant activity in the extracts (Figure 4$)$. Figure 5 shows the comparison between total phenolic and total flavonoid contents (TPC and TF, respectively) and radical scavenging potential (DPPH) expressed in $\left(\mathrm{IC}_{50}\right)$ data in different extracts of $C$. villosus. Figure 5 also shows that the $n$ - $\mathrm{BuOH}$ extract exhibited the highest radical scavenging potential (DPPH) expressed in $\left(\mathrm{IC}_{50}\right)$. Hence, a high phenolic content is an important factor to determinate the antioxidant activity. This result is in agreement with previous studies, reporting that the phenolic compounds significantly contribute to the antioxidant activity in different plant species [49].

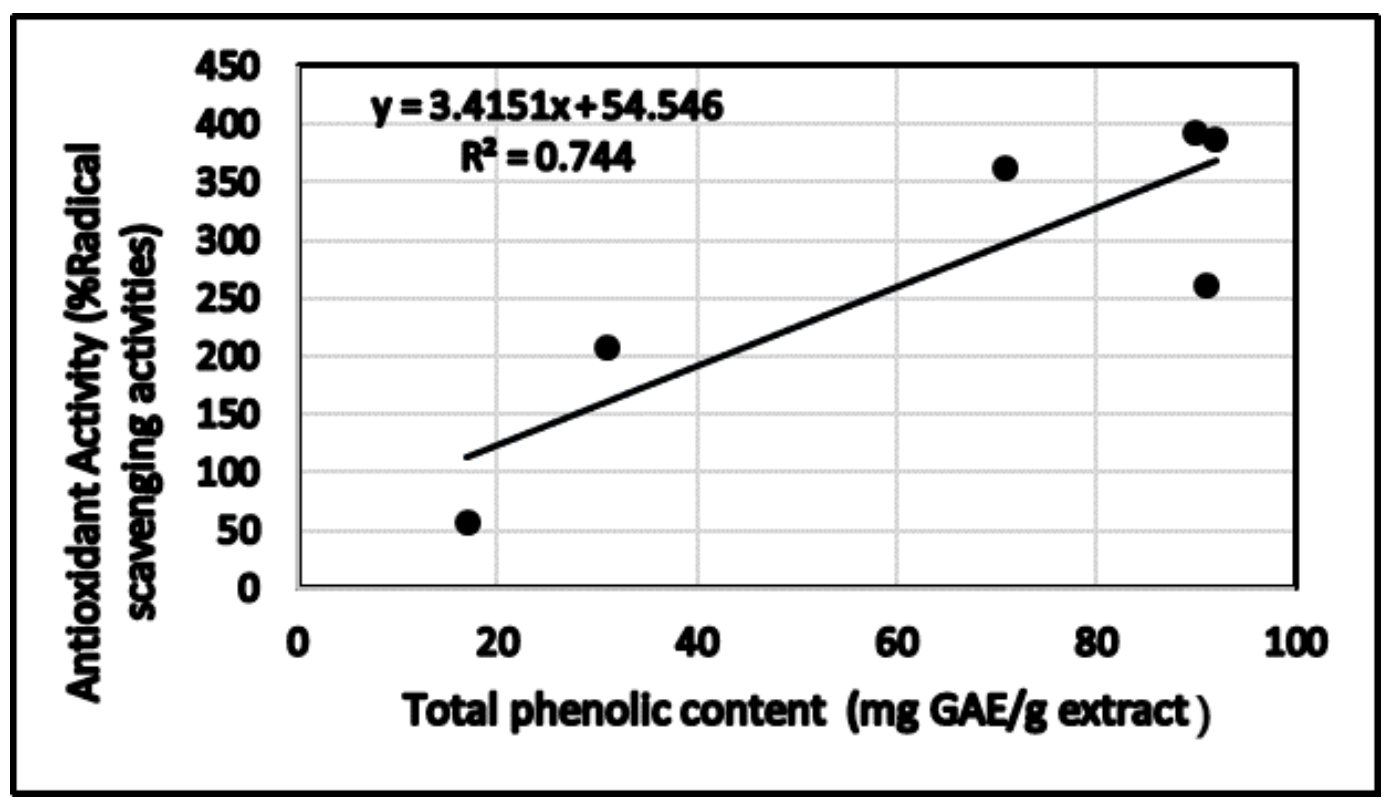

Figure 3. Correlation graphs for DPPH (\% radical scavenging activity) and total phenolic content in the $C$. villosus extracts. 


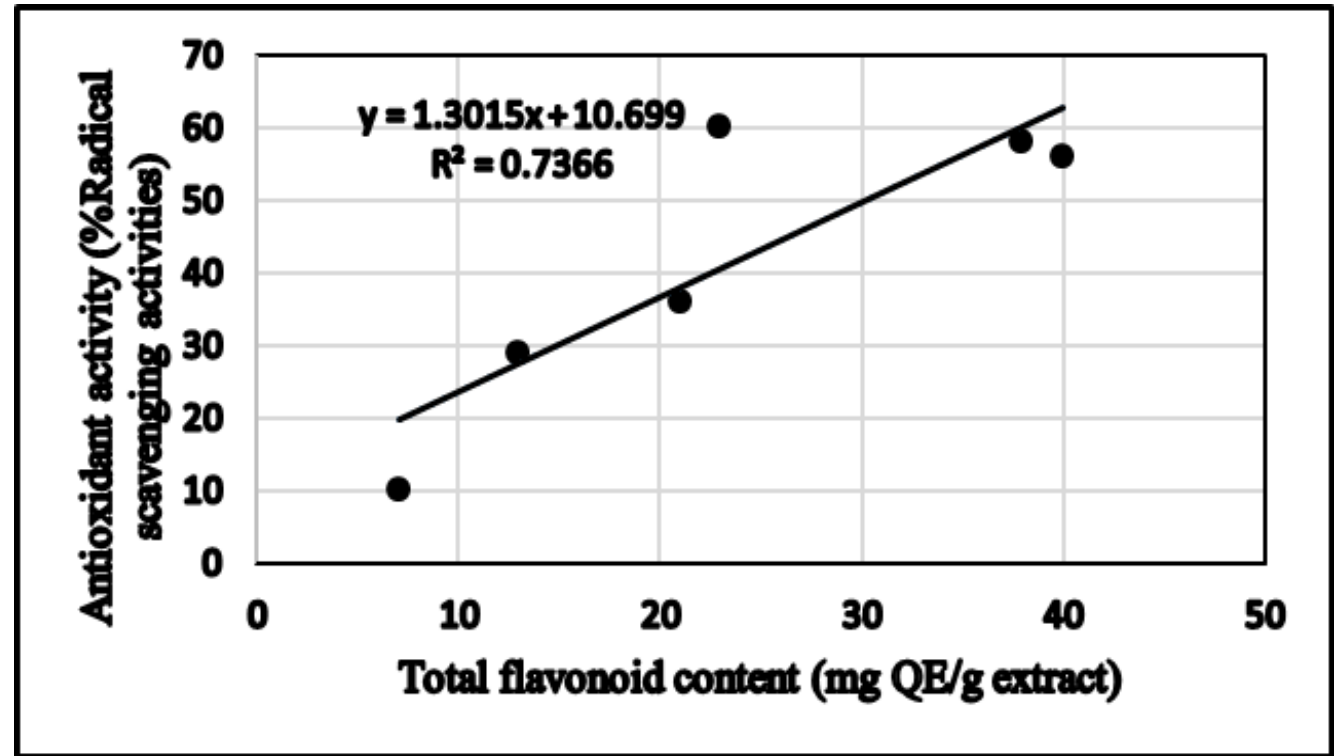

Figure 4. Correlation graphs for DPPH (\% radical scavenging activity) and total flavonoid content in the $C$. villosus extracts.

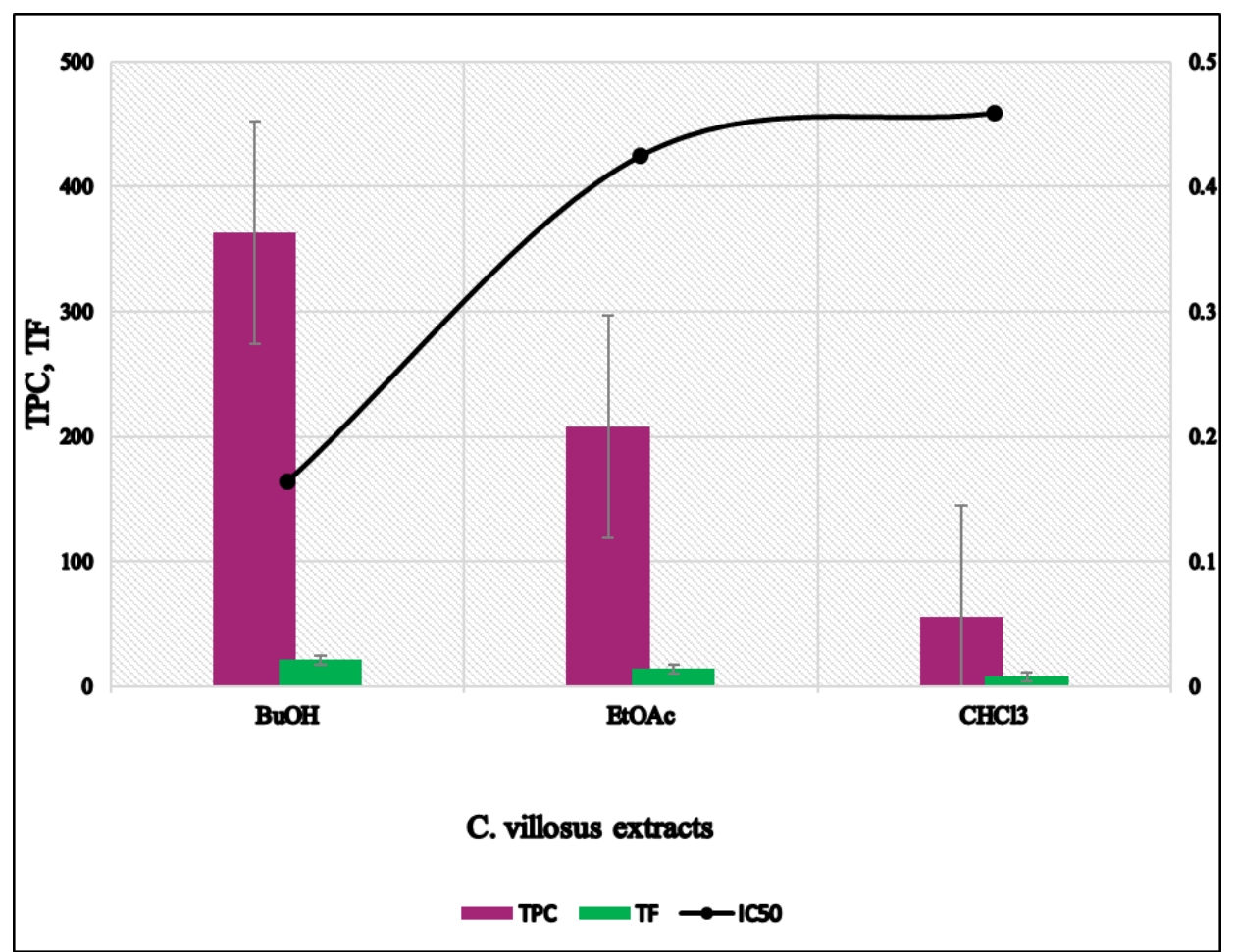

Figure 5. Comparison between total phenolic and total flavonoid content (TPC and TF, respectively) and $\mathrm{DPPH}\left(\mathrm{IC}_{50}\right)$ data in different extracts of $C$. villosus.

In contrast to the antioxidant assays results, the $n-\mathrm{BuOH}$ extract from the $C$. villosus aerial parts showed weak anti-inflammatory activity for the inhibition of iNOS expression, with an $\mathrm{IC}_{50}$ value of $90 \mu \mathrm{g} / \mathrm{mL}$. Whereas the EtOAc extract exhibited higher inhibition of iNOS with an $\mathrm{IC}_{50}$ value of $48 \mu \mathrm{g} / \mathrm{mL}$. The increase in transcriptional activity of NF-kB in PMA-treated cells was not suppressed by the plant's extracts. Among all tested compounds, compound 1 from the EtOAc extract showed good inhibition of iNOS with an $\mathrm{IC}_{50}$ value of $9 \mu \mathrm{g} / \mathrm{mL}$. This compound showed lower inhibition of NF- $\mathrm{kB}$ activity with an $\mathrm{IC}_{50}$ value of $28 \mu \mathrm{g} / \mathrm{mL}$. Previous studies also indicated that genistein (1) 
acts as anti-inflammatory agent [50]. This isoflavone has been reported to have inhibitory effects on iNOS expression and to inhibit the activation of nuclear factor- $\kappa \mathrm{B}(\mathrm{NF}-\kappa \mathrm{B})[51,52]$. Hence, the EtOAc extract could be a good source of phenolics with anti-inflammatory activity. Our results also showed that $n$ - $\mathrm{BuOH}$ extract exhibited potent antitrypanosomal activity against $T$. brucei with an $\mathrm{IC}_{50}$ value of $7.99 \mu \mathrm{g} / \mathrm{mL}$ and an $\mathrm{IC}_{90}$ value of $12.61 \mu \mathrm{g} / \mathrm{mL}$. Compound 4 that was isolated from this extract didn't show an effect against T. brucei. Future examination of the polar components of $C$. villosus, shall determine the active components from the $n-\mathrm{BuOH}$ extract.

The opioid system consists of three receptors, mu, delta, and kappa, which are activated by endogenous opioid peptides (enkephalins, endorphins, and dynorphins). The endogenous cannabinoid system comprises lipid neuromodulators (endocannabinoids), enzymes for their synthesis and their degradation, and two well-characterized receptors, cannabinoid receptors CB1 and CB2 [53]. Evidence has suggested that the opioid system can regulate inflammatory responses in rodents [54]. Mastinou et al. [25], recently described the link between neuroinflammation and cannabinoid systems. The radioligand displacement affinity towards opioid and cannabinoid receptors were evaluated for the extracts and isolated compounds of $C$. villosus. The EtOAc extract exhibited low/moderate activity towards the CB1 and CB2 receptors (32.1\% and $25.2 \%$ displacement) and moderate activity in the delta ( $\delta$ ) opioid receptor ( $31.3 \%$ displacement). Similarly, the $n$-BuOH extract was found to have moderate activity towards CB1, CB2, and delta $(\delta)$ opioid receptors $(33.7 \%, 26.1 \%$ and $24.8 \%$ displacement, respectively). None of the isolated compounds showed activity towards cannabinoid nor opioid receptors.

\section{Conclusions}

In conclusion, we reported the phenolic and flavonoid content, antioxidant, anti-inflammatory, antibacterial, antifungal, antimalarial, antitrypanosomal, antileishmanial, and cytotoxicity activities, in addition to the affinity towards cannabinoid and opioid receptors, of $C$. villosus aerial parts extracts and their isolated compounds. Our results showed that the $n-\mathrm{BuOH}$ extract had the highest phenolic and flavonoid content. Furthermore, $n-\mathrm{BuOH}$ extract produced a potent antitrypanosomal activity that makes it a promising source for the extraction of bioactive components with high activity against human African trypanosomiasis. EtOAc extract was found to exhibit moderate anti-inflammatory activity against iNOS, while the $n$-BuOH extract showed lower inhibitory effect against iNOS. Among isolated compounds, genistein, which isolated from the EtOAc extract, showed the highest anti-inflammatory activity. Further explorations of EtOAc extract could afford more potent anti-inflammatory agents. Although the EtOAc and $n$-BuOH extracts showed moderate activity towards CB1, CB2, and $\delta$ opioid receptors, these results encourage further exploration of Cytisus species and its isolated compounds to study their cannabinoid and opioid receptors activities.

Supplementary Materials: The following are available online at http://www.mdpi.com/2218-273X/9/11/732/s1, Figures S1-S12, spectroscopic data for the isolated compounds.

Author Contributions: Conceptualization, F.L. (Farida Larit) and F.L. (Francisco Leon); methodology, F.L. (Farida Larit) and F.L. (Francisco Leon); software, F.L. (Farida Larit); validation, F.L. (Farida Larit) and F.L. (Francisco Leon); formal analysis, F.L. (Farida Larit); investigation, F.L. (Farida Larit); resources, S.B. and S.J.C.; data curation, F.L. (Farida Larit); writing-original draft preparation, F.L. (Farida Larit); writing-review and editing, F.L. (Farida Larit) and F.L. (Francisco Leon); visualization, F.L. (Francisco Leon); supervision, S.J.C. and F.L. (Francisco Leon); project administration, S.B.; funding acquisition, S.J.C.

Funding: The project described was partially supported by grant number P20GM104932 from the National Institute of General Medical Sciences (NIGMS), a component of the National Institutes of Health (NIH). The content is solely the responsibility of the authors and does not necessarily represent the official views of the NIGMS or the NIH. Furthermore, this investigation was conducted in a facility constructed with support from research facilities improvement program C06RR14503 from the NIH National Center for Research Resources (NCRR).

Acknowledgments: We are grateful to the Algerian Ministry of Higher Education and Scientific Research and the University of Mississippi, School of Pharmacy, Mississippi, USA for their financial support. We are especially thankful to Babu Tekwani, Melissa Jacob, and Shabana I. Khan for providing the antimicrobial, antiprotozoal, 
antioxidant, and anti-inflammatory assays. We are also thankful to the Faculty of Chemistry, University of Opole, Poland, Piotr P. Wieczorek and Izabela Jasicka-Misiak.

Conflicts of Interest: The authors declare no conflict of interest.

\section{References}

1. Rodrigues, T.; Reker, D.; Schneider, P.; Schneider, G. Counting on natural products for drug design. Nat. Chem. 2016, 8, 531-541. [CrossRef] [PubMed]

2. Kumar, S.; Pandey, A.K. Chemistry and biological activities of flavonoids: An overview. Sci. World J. 2013, 2013, 162750. [CrossRef] [PubMed]

3. Quideau, S.; Deffieux, D.; Douat-Casassus, C.; Pouysegu, L. Plant polyphenols: Chemical properties, biological activities, and synthesis. Angewdante Chem. Int. Ed. 2011, 50, 586-621. [CrossRef] [PubMed]

4. Uttara, B.; Singh, A.V.; Zamboni, P.; Mahajan, R.T. Oxidative stress and neurodegenerative diseases: A review of upstream and downstream antioxidant therapeutic options. Curr. Neuropharmacol. 2009, 7, 65-74. [CrossRef] [PubMed]

5. Tak, P.P.; Firestein, G.S. NF-кB: A key role in inflammatory diseases. J. Clin. Investig. 2001, 107, 7-11. [CrossRef]

6. Gutierrez, H.; Davies, A.M. Regulation of neural process growth, elaboration and structural plasticity by NF-кB. Trends Neurosci. 2011, 34, 316-325. [CrossRef]

7. Lanzillotta, A.; Porrini, V.; Bellucci, A.; Benarese, M.; Branca, C.; Parrella, E.; Spano, P.F.; Pizzi, M. NF-kB in innate neuroprotection and age-related neurodegenerative diseases. Front. Neurol. 2015, 6, 98. [CrossRef]

8. Sivandzade, F.; Prasad, S.; Bhalerao, A.; Cucullo, L. NRF2 and NF-kB interplay in cerebrovascular and neurodegenerative disorders: Molecular mechanisms and possible therapeutic approaches. Redox Biol. 2018, 21, 101059. [CrossRef]

9. Bonini, S.A.; Mastinu, A.; Maccarinelli, G.; Mitola, S.; Premoli, M.; La Rosa, L.R.; Ferrari-Toninelli, G.; Grilli, M.; Memo, M. Cortical structure alterations and social behavior impairment in p50-deficient mice. Cereb. Cortex 2016, 26, 2832-2849. [CrossRef]

10. Forrester, S.J.; Kikuchi, D.S.; Hernandes, M.S.; Xu, Q.; Griendling, K.K. Reactive oxygen species in metabolic and inflammatory signaling. Circ. Res. 2018, 122, 877-902. [CrossRef]

11. Zhao, J.; Khan, S.I.; Wang, M.; Vasquez, Y.; Yang, M.H.; Avula, B.; Wang, Y.-H.; Avonto, C.; Smillie, T.J.; Khan, I.A. Octulosonic acid derivatives from Roman chamomile (Chamaemelum nobile) with activities against inflammation and metabolic disorder. J. Nat. Prod. 2014, 77, 509-515. [CrossRef] [PubMed]

12. WHO. Available online: https://www.who.int/leishmaniasis/en/ (accessed on 10 October 2019).

13. Nardella, F.; Gallé, J.B.; Bourjot, M.; Weniger, B.; Vonthron-Sénécheau, C. Antileishmanial and Antitrypanosomal Activities of Flavonoids. In Natural Antimicrobial Agents; Mérillon, J.M., Riviere, C., Eds.; Springer: Cham, Switzerland, 2018; Volume 19.

14. Tasdemir, D.; Kaiser, M.; Brun, R.; Yardley, V.; Schmidt, T.J.; Tosun, F.; Rüedi, P. Chemotherapy. Antitrypanosomal and antileishmanial activities of flavonoids and their analogues: In vitro, in vivo, structure-activity relationship, and quantitative structure-activity relationship studies. Antimicrob. Agents Chemother. 2006, 50, 1352-1364. [CrossRef] [PubMed]

15. Adams, M.; Gmünder, F.; Hamburger, M. Plants traditionally used in age related brain disorders-A survey of ethnobotanical literature. J. Ethnopharmacol. 2007, 113, 363-381. [CrossRef] [PubMed]

16. Schrader, E. Equivalence of St John's wort extract (Ze 117) and fluoxetine: A randomized, controlled study in mildmoderate depression. Int. Clin. Psychopharmacol. 2000, 15, 61-68. [CrossRef]

17. Song, J.-X.; Sze, S.C.-W.; Ng, T.-B.; Lee, C.K.-F.; Leung, G.P.; Shaw, P.-C.; Tong, Y.; Zhang, Y.-B. Anti-Parkinsonian drug discovery from herbal medicines: What have we got from neurotoxic models? J. Ethnopharmacol. 2012, 139, 698-711. [CrossRef]

18. Lundstrom, K.; Pham, H.T.; Dinh, L.D. Interaction of plant extracts with central nervous system receptors. Medicines 2017, 4, 12. [CrossRef]

19. Bonini, S.A.; Premoli, M.; Tambaro, S.; Kumar, A.; Maccarinelli, G.; Memo, M.; Mastinu, A. Cannabis sativa: A comprehensive ethnopharmacological review of a medicinal plant with a long history. J. Ethnopharmacol. 2018, 227, 300-315. [CrossRef] 
20. Kumar, A.; Premoli, M.; Aria, F.; Bonini, S.A.; Maccarinelli, G.; Gianoncelli, A.; Memo, M.; Mastinu, A. Cannabimimetic plants: Are they new cannabinoidergic modulators? Planta 2019, 249, 1681-1694. [CrossRef]

21. Vaidya, B.; Sifat, A.E.; Karamyan, V.T.; Abbruscato, T.J. The neuroprotective role of the brain opioid system in stroke injury. Drug Discov. Today 2018, 23, 1385-1395. [CrossRef]

22. Pradhan, A.A.; Befort, K.; Nozaki, C.; Gaveriaux-Ruff, C.; Kieffer, B.L. The delta opioid receptor: An evolving target for the treatment of brain disorders. Trends Pharmacol. Sci. 2011, 32, 581-590. [CrossRef]

23. Liska, M.G.; Crowley, M.G.; Lippert, T.; Corey, S.; Borlongan, C.V. Delta opioid receptor and peptide: A dynamic therapy for stroke and other neurological disorders. Handb. Exp. Pharmacol. 2018, 247, 277-299. [CrossRef]

24. Basavarajappa, B.S.; Shivakumar, M.; Joshi, V.; Subbanna, S. Endocannabinoid system in neurodegenerative disorders. J. Neurochem. 2017, 142, 624-648. [CrossRef]

25. Mastinu, A.; Premoli, M.; Ferrari-Toninelli, G.; Tambaro, S.; Maccarinelli, G.; Memo, M.; Bonini, S.A. Cannabinoids in health and disease: Pharmacological potential in metabolic syndrome and neuroinflammation. Horm. Mol. Biol. Clin. Investig. 2018, 36. [CrossRef]

26. Iwaszkiewicz, K.; Schneider, J.; Hua, S. Targeting peripheral opioid receptors to promote analgesic and anti-inflammatory actions. Front. Pharmacol. 2013, 4, 132. [CrossRef]

27. Hill, K.P.; Palastro, M.D.; Johnson, B.; Ditre, J.W. Cannabis and pain: A clinical review. Cannabis Cannabinoid Res. 2017, 2, 96-104. [CrossRef]

28. Cristofolini, G.; Troìa, A. A reassesment of the sections of the genus Cytisus Desf. (Cytiseae, Leguminosae). Taxon 2006, 55, 733-746. [CrossRef]

29. González, N.; Ribeiro, D.; Fernandes, E.; Nogueira, D.R.; Conde, E.; Moure, A.; Vinardell, M.P.; Mitjans, M.; Domínguez, H.; Biology, P.B. Potential use of Cytisus scoparius extracts in topical applications for skin protection against oxidative damage. J. Photochem. Photobiol. B Biol. 2013, 125, 83-89.

30. Sundararajan, R.; Haja, N.A.; Venkatesan, K.; Mukherjee, K.; Saha, B.P.; Bandyopadhyay, A.; Mukherjee, P.K. Cytisus scoparius link-A natural antioxidant. BMC Complementary Altern. Med. 2006, 6, 8. [CrossRef]

31. Nirmal, J.; Babu, C.S.; Harisudhan, T.; Ramanathan, M. Evaluation of behavioural and antioxidant activity of Cytisus scoparius Link in rats exposed to chronic unpredictable mild stress. BMC Complementary Altern. Med. 2008, 8, 15. [CrossRef]

32. Pereira, O.R.; Silva, A.M.; Domingues, M.R.; Cardoso, S.M. Identification of phenolic constituents of Cytisus multiflorus. Food Chem. 2012, 131, 652-659. [CrossRef]

33. Larit, F.; Nael, M.A.; Benyahia, S.; Radwan, M.M.; Leon, F.; Jasicka-Misiak, I.; Poliwoda, A.; Wieczorek, D.; Benayache, F.; Benayache, S. Secondary metabolites from the aerial parts of Cytisus villosus Pourr. Phytochem. Lett. 2018, 24, 1-5. [CrossRef]

34. Larit, F.; Elokely, K.M.; Chaurasiya, N.D.; Benyahia, S.; Nael, M.A.; León, F.; Abu-Darwish, M.S.; Efferth, T.; Wang, Y.-H.; Belouahem-Abed, D. Inhibition of human monoamine oxidase A and B by flavonoids isolated from two Algerian medicinal plants. Phytomedicine 2018, 40, 27-36. [CrossRef]

35. Tuberoso, C.I.G.; Rosa, A.; Bifulco, E.; Melis, M.P.; Atzeri, A.; Pirisi, F.M.; Dessì, M.A. Chemical composition and antioxidant activities of Myrtus communis L. berries extracts. Food Chem. 2010, 123, 1242-1251. [CrossRef]

36. Chang, C.-C.; Yang, M.-H.; Wen, H.-M.; Chern, J.-C. Estimation of total flavonoid content in propolis by two complementary colorimetric methods. J. Food Drug Anal. 2002, 10, 178-182.

37. Marinova, D.; Ribarova, F.; Atanassova, M. Total phenolics and total flavonoids in Bulgarian fruits and vegetables. J. Univ. Chem. Technol. Metall. 2005, 40, 255-260.

38. Brand-Williams, W.; Cuvelier, M.-E.; Berset, C. Use of a free radical method to evaluate antioxidant activity. Lwt-Food Sci. Technol. 1995, 28, 25-30. [CrossRef]

39. Wolfe, K.L.; Liu, R.H. Cellular antioxidant activity (CAA) assay for assessing antioxidants, foods, and dietary supplements. J. Agric. Food Chem. 2007, 55, 8896-8907. [CrossRef]

40. Chandra, S.; Khan, S.; Avula, B.; Lata, H.; Yang, M.H.; ElSohly, M.A.; Khan, I.A. Assessment of total phenolic and flavonoid content, antioxidant properties, and yield of aeroponically and conventionally grown leafy vegetables and fruit crops: A comparative study. Evid. -Based Complementary Altern. Med. 2014, 2014, 253875. [CrossRef]

41. Zaki, M.A.; Balachandran, P.; Khan, S.; Wang, M.; Mohammed, R.; Hetta, M.H.; Pasco, D.S.; Muhammad, I. Cytotoxicity and modulation of cancer-related signaling by (Z)-and (E)-3, 4, 3', 5' -tetramethoxystilbene isolated from Eugenia rigida. J. Nat. Prod. 2013, 76, 679-684. [CrossRef] 
42. Ma, G.; Khan, S.I.; Benavides, G.; Schühly, W.; Fischer, N.H.; Khan, I.A.; Pasco, D.S. Inhibition of NF-kB-mediated transcription and induction of apoptosis by melampolides and repandolides. Cancer Chemother. Pharmacol. 2007, 60, 35-43. [CrossRef]

43. Manda, S.; Khan, S.I.; Jain, S.K.; Mohammed, S.; Tekwani, B.L.; Khan, I.A.; Vishwakarma, R.A.; Bharate, S.B. Synthesis, antileishmanial and antitrypanosomal activities of $N$-substituted tetrahydro- $\beta$-carbolines. Bioorganic Med. Chem. Lett. 2014, 24, 3247-3250. [CrossRef]

44. Jain, S.K.; Sahu, R.; Walker, L.A.; Tekwani, B.L. A parasite rescue and transformation assay for antileishmanial screening against intracellular Leishmania donovani amastigotes in THP1 human acute monocytic leukemia cell line. J. Vis. Exp. 2012, 70. [CrossRef]

45. Bharate, S.B.; Khan, S.I.; Yunus, N.A.; Chauthe, S.K.; Jacob, M.R.; Tekwani, B.L.; Khan, I.A.; Singh, I. P Antiprotozoal and antimicrobial activities of $O$-alkylated and formylated acylphloroglucinols. Bioorganic Med. Chem. 2007, 15, 87-96. [CrossRef] [PubMed]

46. Samoylenko, V.; Jacob, M.R.; Khan, S.I.; Zhao, J.; Tekwani, B.L.; Midiwo, J.O.; Walker, L.A.; Muhammad, I. Antimicrobial, antiparasitic and cytotoxic spermine alkaloids from Albizia schimperiana. Nat. Prod. Commun. 2009, 4, 791-796. [CrossRef] [PubMed]

47. Borenfreund, E.; Babich, H.; Martin-Alguacil, N. Rapid chemosensitivity assay with human normal and tumor cells in vitro. In Vitro Cell. Dev. Biol. 1990, 26, 1030-1034. [CrossRef]

48. Tarawneh, A.; León, F.; Pettaway, S.; Elokely, K.M.; Klein, M.L.; Lambert, J.; Mansoor, A.; Cutler, S.J. Flavonoids from Perovskia atriplicifolia and their in vitro displacement of the respective radioligands for human opioid and cannabinoid receptors. J. Nat. Prod. 2015, 78, 1461-1465. [CrossRef]

49. Zielinski, A.A.F.; Haminiuk, C.W.I.; Alberti, A.; Nogueira, A.; Demiate, I.M.; Granato, D. A comparative study of the phenolic compounds and the in vitro antioxidant activity of different Brazilian teas using multivariate statistical techniques. Food Res. Int. 2014, 60, 246-254. [CrossRef]

50. Verdrengh, M.; Jonsson, I.; Holmdahl, R.; Tarkowski, A. Genistein as an anti-inflammatory agent. Inflamm. Res. 2003, 52, 341-346. [CrossRef]

51. Lu, H.; Shi, J.-X.; Zhang, D.-M.; Wang, H.-D.; Hang, C.-H.; Chen, H.-L.; Yin, H.-X. Inhibition of hemolysate-induced iNOS and COX-2 expression by genistein through suppression of NF- $\mathrm{KB}$ activation in primary astrocytes. J. Neurol. Sci. 2009, 278, 91-95. [CrossRef]

52. Hämäläinen, M.; Nieminen, R.; Vuorela, P.; Heinonen, M.; Moilanen, E. Anti-inflammatory effects of flavonoids: Genistein, kaempferol, quercetin, and daidzein inhibit STAT-1 and NF- $\mathrm{kB}$ activations, whereas flavone, isorhamnetin, naringenin, and pelargonidin inhibit only NF- $\mathrm{B}$ activation along with their inhibitory effect on iNOS expression and NO production in activated macrophages. Mediat. Inflamm. 2007, 2007, 45673.

53. Befort, K. Interactions of the opioid and cannabinoid systems in reward: Insights from knockout studies. Front. Pharmacol. 2015, 6, 6. [PubMed]

54. Planas, M.E.; Rodriguez, L.; Sanchez, S.; Puig, M.M. Pharmacological evidence for the involvement of the endogenous opioid system in the response to local inflammation in the rat paw. Pain 1995, 60,67-71. [CrossRef]

(C) 2019 by the authors. Licensee MDPI, Basel, Switzerland. This article is an open access article distributed under the terms and conditions of the Creative Commons Attribution (CC BY) license (http://creativecommons.org/licenses/by/4.0/). 